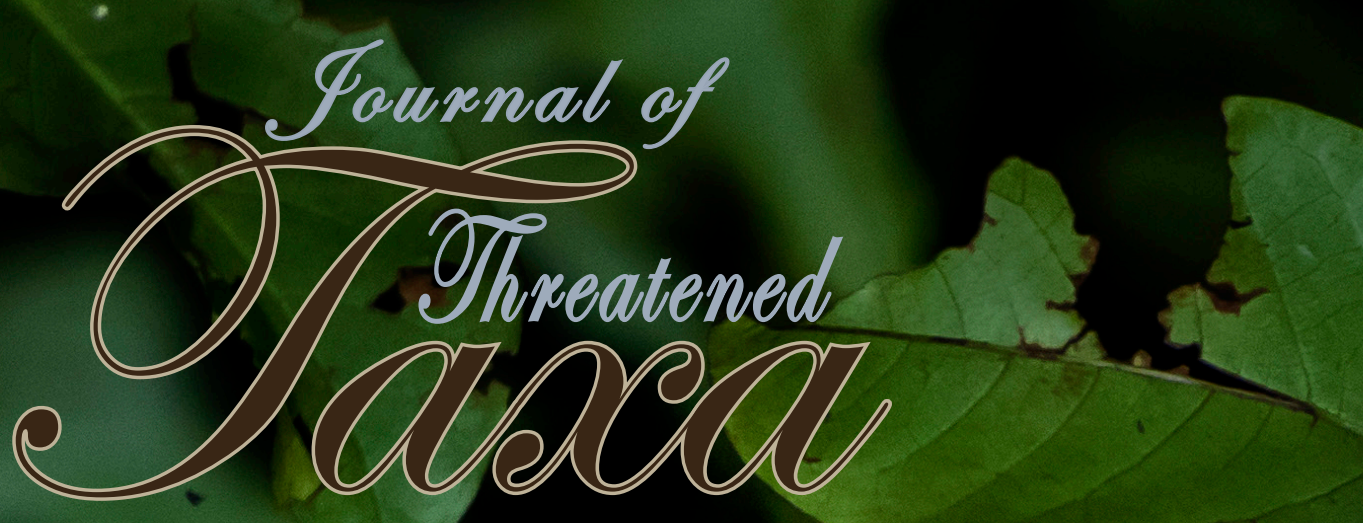

Building exidence for conservation glabally

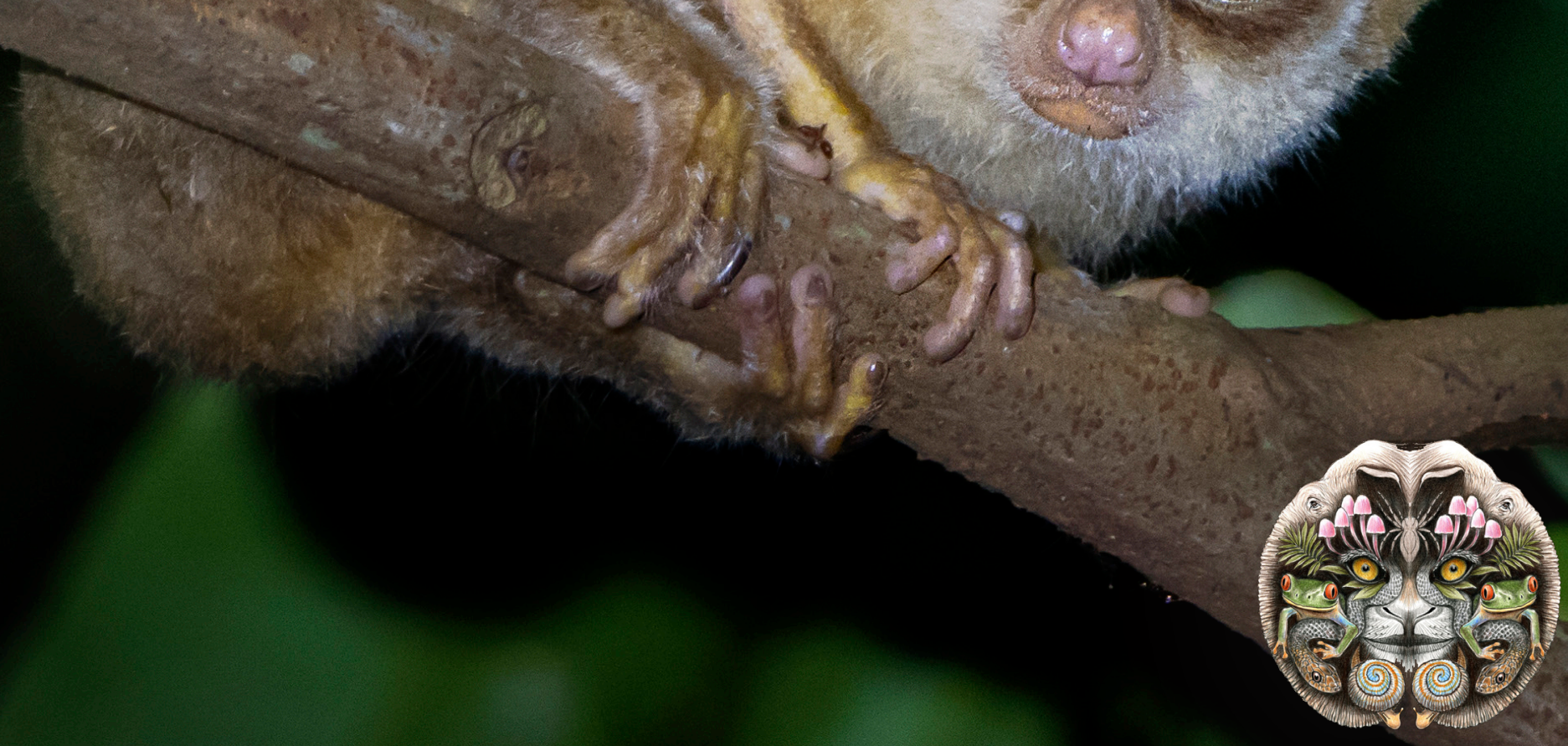

Open Access

$10.11609 /$ jott.2021.13.010.19431-19614 creven.threatenedtaxa.arg

26 September 2021 (Online \& Print) Val. 13 | Na. 11 | Pages: 19431-19674 


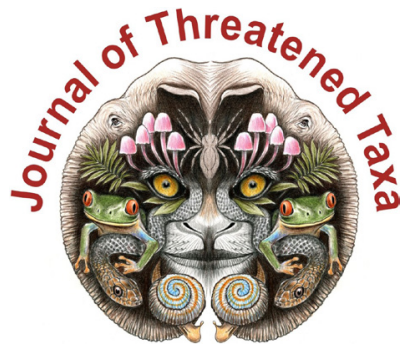

ISSN 0974-7907 (Online); ISSN $0974-7893$ (Print)

Publisher

Host

Wildlife Information Liaison Development Society

www.wild.zooreach.org

Zoo Outreach Organization www.zooreach.org

No. 12, Thiruvannamalai Nagar, Saravanampatti - Kalapatti Road, Saravanampatti, Coimbatore, Tamil Nadu 641035, India

Ph: +91 9385339863 | www.threatenedtaxa.org

Email: sanjay@threatenedtaxa.org

EDITORS

\section{Founder \& Chief Editor}

Dr. Sanjay Molur

Wildlife Information Liaison Development (WILD) Society \& Zoo Outreach Organization (ZOO)

12 Thiruvannamalai Nagar, Saravanampatti, Coimbatore, Tamil Nadu 641035, India

\section{Deputy Chief Edito}

Dr. Neelesh Dahanukar

Noida, Uttar Pradesh, India

\section{Managing Editor}

Mr. B. Ravichandran, WILD/ZOO, Coimbatore, India

\section{Associate Editors}

Dr. Mandar Paingankar, Government Science College Gadchiroli, Maharashtra 442605, India

Dr. Ulrike Streicher, Wildlife Veterinarian, Eugene, Oregon, USA

Ms. Priyanka Iyer, ZOO/WILD, Coimbatore, Tamil Nadu 641035, India

Dr. B. A. Daniel, $200 / \mathrm{WILD}$, Coimbatore, Tamil Nadu 641035, India

\section{Editorial Board}

Dr. Russel Mittermeier

Executive Vice Chair, Conservation International, Arlington, Virginia 22202, USA

\section{Prof. Mewa Singh Ph.D., FASc, FNA, FNASc, FNAPsy}

Ramanna Fellow and Life-Long Distinguished Professor, Biopsychology Laboratory, and Institute of Excellence, University of Mysore, Mysuru, Karnataka 570006, India; Honorary Professor, Jawaharlal Nehru Centre for Advanced Scientific Research, Bangalore; and Adjunct Professor, National Institute of Advanced Studies, Bangalore

\section{Stephen D. Nash}

Scientific Illustrator, Conservation International, Dept. of Anatomical Sciences, Health Sciences Center, T-8, Room 045, Stony Brook University, Stony Brook, NY 11794-8081, USA

\section{Dr. Fred Pluthero}

Toronto, Canada

\section{Dr. Priya Davidar}

Sigur Nature Trust, Chadapatti, Mavinhalla PO, Nilgiris, Tamil Nadu 643223, India

\section{Dr. Martin Fisher}

Senior Associate Professor, Battcock Centre for Experimental Astrophysics, Cavendish

Laboratory, JJ Thomson Avenue, Cambridge CB3 OHE, UK

\section{Dr. John Fellowe}

Honorary Assistant Professor, The Kadoorie Institute, 8/F, T.T. Tsui Building, The University of Hong Kong, Pokfulam Road, Hong Kong

\section{Prof. Dr. Mirco Solé}

Universidade Estadual de Santa Cruz, Departamento de Ciências Biológicas, Vice-coordenado do Programa de Pós-Graduação em Zoologia, Rodovia Ilhéus/Itabuna, Km 16 (45662-000)

Salobrinho, Ilhéus - Bahia - Brasil

\section{Dr. Rajeev Raghavan}

Professor of Taxonomy, Kerala University of Fisheries \& Ocean Studies, Kochi, Kerala, India

\section{English Editors}

Mrs. Mira Bhojwani, Pune, India

Dr. Fred Pluthero, Toronto, Canad

Mr. P. Ilangovan, Chennai, India

Web Maintenance

Mrs. Latha G. Ravikumar, ZOO/WILD, Coimbatore, India

\section{Typesetting}

Mr. Arul Jagadish, ZOO, Coimbatore, India

Mrs. Radhika, ZOO, Coimbatore, India

Mrs. Geetha, ZOO, Coimbatore India

\section{Fundraising/Communications}

Mrs. Payal B. Molur, Coimbatore, India

Subject Editors 2018-2020

Fungi

Dr. B. Shivaraju, Bengaluru, Karnataka, India

Dr. R.K. Verma, Tropical Forest Research Institute, Jabalpur, India

Dr. Vatsavaya S. Raju, Kakatiay University, Warangal, Andhra Pradesh, India

Dr. M. Krishnappa, Jnana Sahyadri, Kuvempu University, Shimoga, Karnataka, India

Dr. K.R. Sridhar, Mangalore University, Mangalagangotri, Mangalore, Karnataka, India

Dr. Gunjan Biswas, Vidyasagar University, Midnapore, West Bengal, India

Plants

Dr. G.P. Sinha, Botanical Survey of India, Allahabad, India

Dr. N.P. Balakrishnan, Ret. Joint Director, BSI, Coimbatore, India

Dr. Shonil Bhagwat, Open University and University of Oxford, UK

Prof. D.J. Bhat, Retd. Professor, Goa University, Goa, India

Dr. Ferdinando Boero, Università del Salento, Lecce, Italy

Dr. Dale R. Calder, Royal Ontaro Museum, Toronto, Ontario, Canada

Dr. Cleofas Cervancia, Univ. of Philippines Los Baños College Laguna, Philippines

Dr. F.B. Vincent Florens, University of Mauritius, Mauritius

Dr. Merlin Franco, Curtin University, Malaysia

Dr. V. Irudayaraj, St. Xavier's College, Palayamkottai, Tamil Nadu, India

Dr. B.S. Kholia, Botanical Survey of India, Gangtok, Sikkim, India

Dr. Pankaj Kumar, Kadoorie Farm and Botanic Garden Corporation, Hong Kong S.A.R., China

Dr. V. Sampath Kumar, Botanical Survey of India, Howrah, West Bengal, India

Dr. A.J. Solomon Raju, Andhra University, Visakhapatnam, India

Dr. Vijayasankar Raman, University of Mississippi, USA

Dr. B. Ravi Prasad Rao, Sri Krishnadevaraya University, Anantpur, India

Dr. K. Ravikumar, FRLHT, Bengaluru, Karnataka, India

Dr. Aparna Watve, Pune, Maharashtra, India

Dr. Qiang Liu, Xishuangbanna Tropical Botanical Garden, Yunnan, China

Dr. Noor Azhar Mohamed Shazili, Universiti Malaysia Terengganu, Kuala Terengganu, Malaysia Dr. M.K. Vasudeva Rao, Shiv Ranjani Housing Society, Pune, Maharashtra, India

Prof. A.J. Solomon Raju, Andhra University, Visakhapatnam, India

Dr. Mandar Datar, Agharkar Research Institute, Pune, Maharashtra, India

Dr. M.K. Janarthanam, Goa University, Goa, India

Dr. K. Karthigeyan, Botanical Survey of India, India

Dr. Errol Vela, University of Montpellier, Montpellier, France

Dr. P. Lakshminarasimhan, Botanical Survey of India, Howrah, India

Dr. Larry R. Noblick, Montgomery Botanical Center, Miami, USA

Dr. K. Haridasan, Pallavur, Palakkad District, Kerala, India

Dr. Analinda Manila-Fajard, University of the Philippines Los Banos, Laguna, Philippines

Dr. P.A. Sinu, Central University of Kerala, Kasaragod, Kerala, India

Dr. Afroz Alam, Banasthali Vidyapith (accredited A grade by NAAC), Rajasthan, India

Dr. K.P. Rajesh, Zamorin's Guruvayurappan College, GA College PO, Kozhikode, Kerala, India

Dr. David E. Boufford, Harvard University Herbaria, Cambridge, MA 02138-2020, USA

Dr. Ritesh Kumar Choudhary, Agharkar Research Institute, Pune, Maharashtra, India

Dr. Navendu Page, Wildlife Institute of India, Chandrabani, Dehradun, Uttarakhand, India

Invertebrates

Dr. R.K. Avasthi, Rohtak University, Haryana, India

Dr. D.B. Bastawade, Maharashtra, India

Dr. Partha Pratim Bhattacharjee, Tripura University, Suryamaninagar, India

Dr. Kailash Chandra, Zoological Survey of India, Jabalpur, Madhya Pradesh, India

Dr. Ansie Dippenaar-Schoeman, University of Pretoria, Queenswood, South Africa

Dr. Rory Dow, National Museum of natural History Naturalis, The Netherlands

Dr. Brian Fisher, California Academy of Sciences, USA

Dr. Richard Gallon, llandudno, North Wales, LL30 1UP

Dr. Hemant V. Ghate, Modern College, Pune, India

Dr. M. Monwar Hossain, Jahangirnagar University, Dhaka, Bangladesh

Mr. Jatishwor Singh Irungbam, Biology Centre CAS, Branišovská, Czech Republic

Dr. lan J. Kitching Natural History Museum, Cromwell Road, UK

Dr. George Mathew, Kerala Forest Research Institute, Peechi, India

Dr. John Noyes, Natural History Museum, London, UK

For Focus, Scope, Aims, and Policies, visit https://threatenedtaxa.org/index.php/JoTT/aims_scope
For Article Submission Guidelines, visit https://threatenedtaxa.org/index.php/JoTT/about/submissions
For Policies against Scientific Misconduct, visit https://threatenedtaxa.org/index.php/JoTT/policies_various 


\title{
New distribution records of two Begonias to the flora of Bhutan
}

\author{
Phub Gyeltshen ${ }^{1}$ (ID $\&$ Sherab Jamtsho ${ }^{2}$ (D)
}

\author{
${ }^{1}$ Bumthang Forest Division, Department of Forest and Park Services, Trongsa, Nubi-33001, Bhutan. \\ ${ }^{2}$ Zhemgang Forest Division, Department of Forest Park Services, Zhemgang, Shingkhar-3400, Bhutan. \\ ${ }^{1}$ gyeltshenforest@gmail.com (corresponding author), ${ }^{2}$ sherabjamtsho85@gmail.com
}

Abstract: Two species of Begonia are collected and described for the flora of Bhutan-panchtharensis and gemmipara. A detailed description, ecology, distribution, notes and photographs of the recorded species are provided.

Keywords: Begoniaceae, Begonia gemmipara, Begonia panchtharensis, conservation status, description, ecology, morphology, Thimphu.

The genus Begonia L. (Begoniaceae) comprises of more than 2000 accepted species (Hughes et al. 2015), currently divided into 70 sections, distributed throughout tropical, subtropical (Doorenbos et al. 1998; Moonlight et al. 2018) and temperate regions of the world. In Asia, 959 species in 19 sections have been recorded, with maximum distribution in southeastern Asia (Doorenbos et al. 1998; Shui et al. 2002; Moonlight et al. 2018). In Bhutan, Grierson (1991) described 20 species of which 13 are known, and the addition of Begonia flaviflora Hara by Gyeltshen et al. (2021) increased the number of species to 14 . The present report provides two additional new records of Begonia for Bhutan.

During a recent botanical exploration to central Bhutan between June and August 2020, small natural populations of Begonia species were observed in the shady and moist areas in cool and warm broadleaved forests. The authors collected detailed field notes and specimens for further examination. After detailed study on its morphological characteristics and reviewing the literature (Clarke 1879; Hara 1971; Grierson 1991; Tsuechih et al. 1999; Rajbhandary et al. 2010; Camfield \& Hughes 2018; Pradhan et al. 2019) and consultation of herbarium specimens available at the Global Biodiversity Information Facility (GBIF 2020), it was identified as Begonia panchtharensis Rajbhandary (sect. Platycentrum (Klotzsch) A.DC) and Begonia gemmipara Hook.f. \& Thomson (sect. Putyzeysia (Klotzsch) A.DC.). Grierson (1991) incorporated brief descriptions of B. gemmipara in the Flora of Bhutan based on the specimens collected from Darjeeling and Sikkim states of India. B. panchtharensis is a recently described species and is so far known from Nepal and Sikkim state of India (Pradhan et al. 2019). Detailed morphological descriptions, phenology, ecology, distribution, notes, and photographs are provided based on the collected specimens. The voucher specimens are deposited at the National Herbarium (THIM), National Biodiversity Centre, Thimphu, Bhutan.

Copyright: (c) Gyeltshen \& Jamtsho 2021. Creative Commons Attribution 4.0 International License. JoTT allows unrestricted use, reproduction, and distribution of this article in any medium by providing adequate credit to the author(s) and the source of publication.

Funding: Self-funded.

Competing interests: The authors declare no competing interests.

Acknowledgements: Authors would like to express sincere gratitude to the Director of the Department of Forest and Park Services; Chief Forestry Officers, and staff of Bumthang and Zhemgang forest divisions for their constant motivation and encouragement. We also extend our thanks to Dr. Mark Hughes and Dave Long for providing information on Begonia gemmipara and sharing herbarium specimens. 


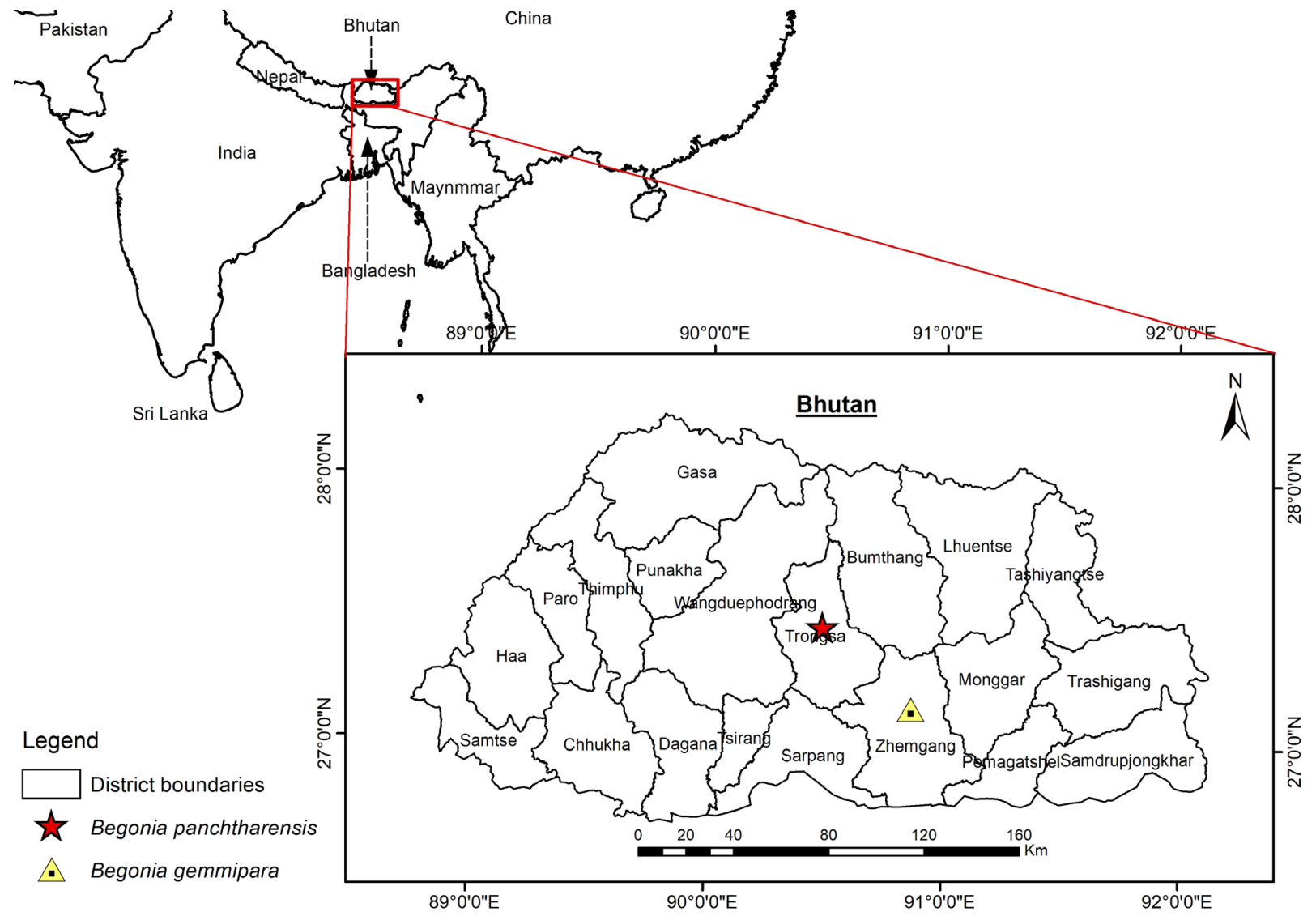

Figure 1. Distribution map for Begonia panchtharensis and Begonia gemmipara in Bhutan.

\section{TAXONOMIC ENUMERATION}

\section{Begonia panchtharensis S. Rajbhandary}

Gard. Bull. Singapore 62(1): 151-162. 2010

Type: Nepal, Panchthar, Tinubote, Sisire, Prangbung, VDC, 2,240-2,300 m, 2.x.2007, U. Thamsuhang s.n., vouchered as S. Rajbhandary S74 (holotype, E, isotype, KATH) (Image 1).

Plant monoecious, rhizomatous herb, $40-90 \mathrm{~cm}$ tall. Rhizomes, 10-25 long and 2-3.5 cm diameter covered with long adventitious roots. Stipules broadly ovate, 20-30 x 8.5-14 mm, caducous, membranous, pinkishwhite with light green tinge, glabrous, red spotted on the abaxial surface, apex acuminate. Leaves arising from the rhizome; petioles $25-75 \mathrm{~cm}$ long $\times$ 7-12 mm wide, cylindrical with two parallel grooves on adaxial surface, glabrous, yellowish-green with red striated spots on the surfaces; blades slightly asymmetric, sub-orbicular, 20$42 \times 18-40 \mathrm{~cm}$, deeply lobed, adaxial surface dark green with sparsely white hirsute, abaxial surface pale green, glabrous with sparse white hairs on veins, base strongly cordate, margin irregularly serrulate or dentate, lobes 6-8, apex acuminate, palmately $6-8$ veined.
Inflorescences terminal or axillary, cymose, dichotomously branched, 30-75 cm long, female inflorescences longer than male inflorescences; peduncles cylindrical, 25-48 cm long, glabrous, semiwoody, yellowish-green with red linear spots on the surface.

Floral bracts ovate-elliptic or elliptic, 2-3.5 x 1.5-2.0 $\mathrm{cm}$, caducous, membranous, pinkish, glabrous, margin entire, apex acuminate, abaxial surface with circular or linear spots. Staminate flowers: pedicel $1.5-2.5 \mathrm{~cm}$ long, pale whitish-pink or white, glabrous with few red spots; tepals four, white to pale pink, 9-11 veined; outer two tepals broadly ovate, $15-24 \times 10-15 \mathrm{~mm}$, glabrous, apex sub-acute, base truncate, margin entire; inner two tepals oblanceolate to obovate, 20-22 x 10-12 mm, white, glabrous, apex obtuse, base cuneate, margin entire; stamens numerous, up to $5 \mathrm{~mm}$ long, distal filaments and anthers are longer than basal ones; filaments free, 2-3 $\mathrm{mm}$ long, obovate-oblong to elliptic-oblanceolate, 1.5-2 mm long, golden yellow, anther connectives extended. Pistillate flowers: pedicel up to 12-15 mm long, pale greenish-white or white with short linear red spots; tepals 5, unequal, white, glabrous, margin entire; 


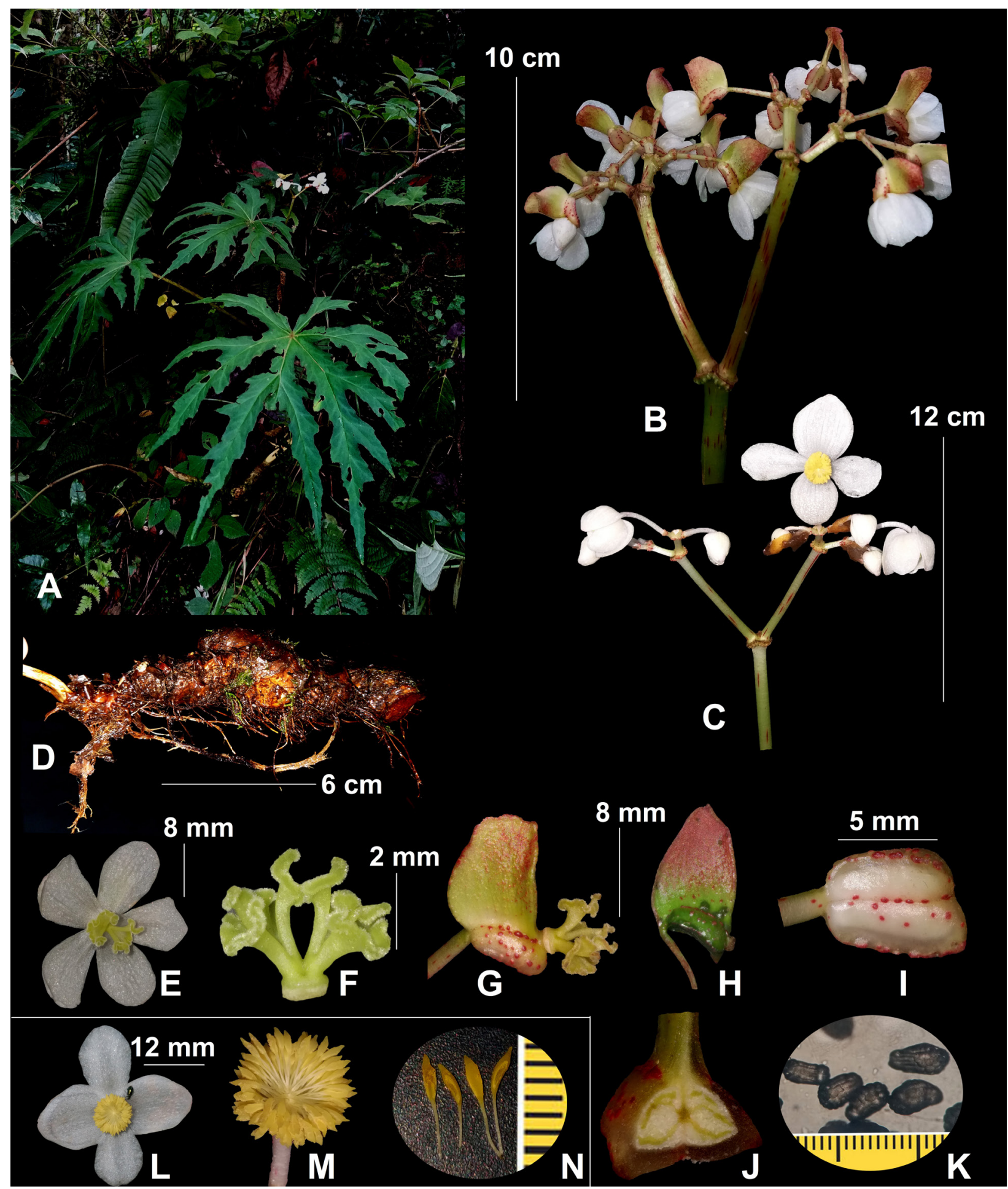

Image 1. Begonia panchtharensis Rajbhandary: A-Habit | B \& C-Inflorescences (Female and male) | D-Rhizome | E-Pistillate flower | F-Styles | G, H \& I-Fruits (Side and abaxial view) | J-Transversal section of ovary | K-Seeds | L-Staminate flower | M \& N-Stamens. (c) Phub Gyeltshen

outer three tepals, obovate or ovate-elliptic, 15-16 $\mathrm{x}$ 9-12 $\mathrm{mm}$, apex obtuse or rounded, base truncate, 8-9 veined; inner two tepals, obovate to oblanceolate, 1315 x 7-11 mm, apex obtuse or rounded, base truncate; styles 2, persistent, 3-5 $\mathrm{mm}$ long, fused at base, golden yellow; stigma inner margins thickened and spiraled, intermediate portions flat and undulated, papillose; ovary oblong, slightly curved downwards, 6.5-8.5 x 


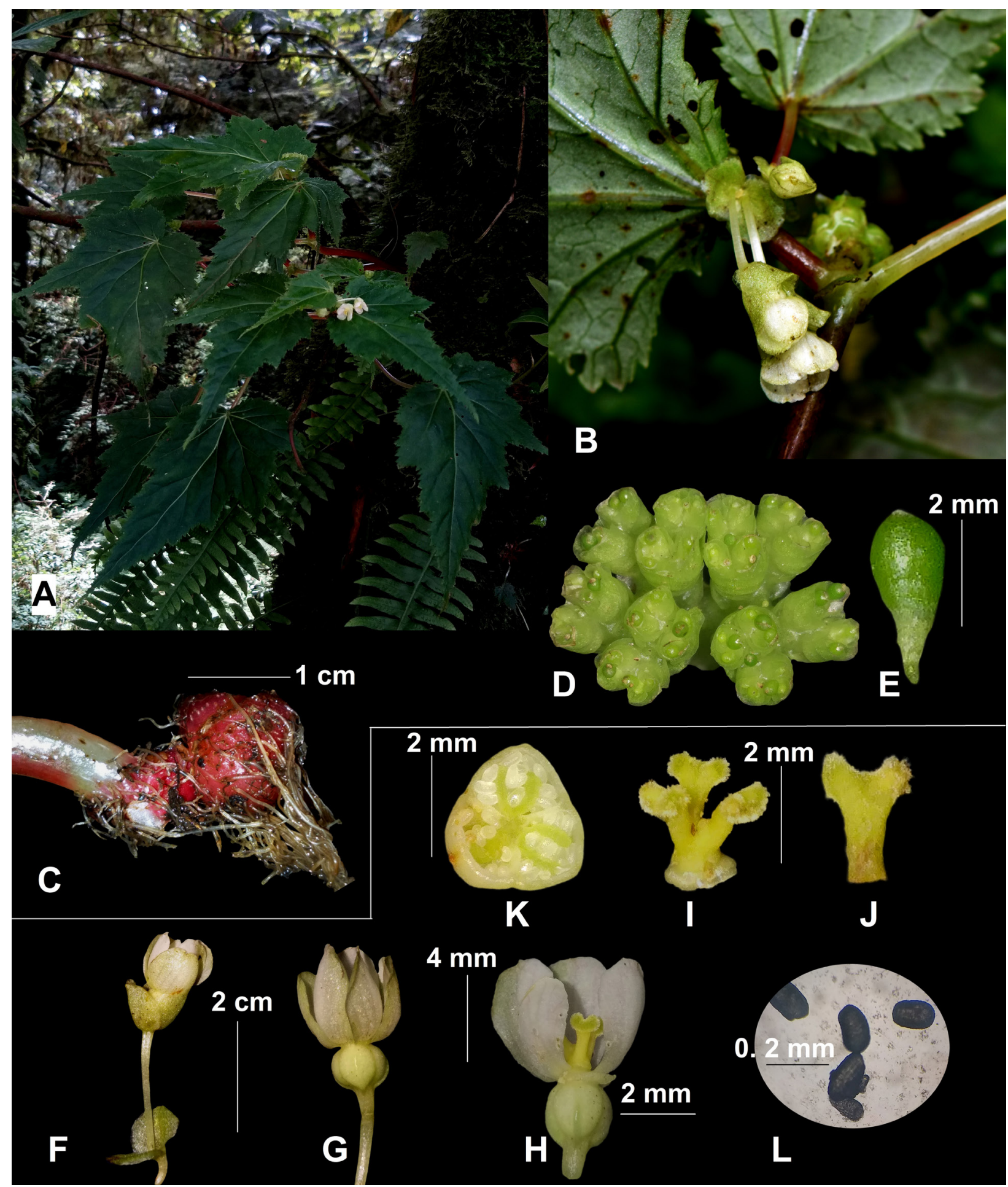

Image 2. Begonia gemmipara Hook.f. \& Thomson: A-Habit | B-Inflorescences attached to stem | C-Tuber | D-Gemma-up like structure | E-Bulbil | F-Inflorescence | G-Inflorescence without bracts | H-Female flower showing ovary and styles | I \& J-Styles | K-Transversal section | L-Seeds. [C) Phub Gyeltshen

4-5 mm, glabrous, red circular or linear granules on the surface with three unequal wings, dorsal wing longer than the two lateral underdeveloped ridge like wings, 2-locular, placentation axillary with two branches per locule. Fruits nodding or pendant, 7-9 × 5-6 mm, slightly falcate, yellow-green, nodding; dorsal wing obovoid or obovoid-oblong, 8-10 x 11-15 mm, wavy, margin flashed with red spots to $2 / 3$ of upper portions; lateral 
wings 8-9 x $1 \mathrm{~mm}$, red tubercles on the wings; seeds oblong, $0.5 \mathrm{~mm}$ long.

Specimens examined: Barcode No. THIM15584, 10.viii.2019, Bhutan: Trongsa, Tashidingkha, $27.4512^{\circ} \mathrm{N}$, $90.4833^{\circ} \mathrm{E}, 1,898 \mathrm{~m}$, coll. P. Gyeltshen, coll. no. 018 - 019.

Phenology: Flowering and fruiting July to September.

Habitat and ecology: The plant is lithophytes in the shady rocky areas in the warm broadleaved forest at 1,898-2,070 m elevation. The associated species includes Globba clarkei, Elatostema sp., Sonerila khasiana, Begonia josephii, and Persicaria chinensis.

Distribution: India, Nepal, and new to Bhutan (Fig. 1).

Notes: The current distribution sites are located within road buffer and the natural habitat could be disturbed or changed due to road expansion and maintenance in future. This species is encountered in the two locations with population less than 10 individuals in the field. Further study is recommended to understand its population trend and conservation status.

\section{Begonia gemmipara Hook.f. \& Thomson III.}

Himal. PI. t. 14. 1855

C.B.Clarke in Hook.f. Fl. Brit. India 2: 641. 1879; Hara in Flora of Eastern Himalaya 2:84.1971; Hara in Hara and Williams, Enum. FI. PI. Nepal 2: 181. 1979; Grierson in Grierson and Long, Flora of Bhutan 2(1): 237-246. 1991.

Putzeysia gemmipara (Hook.f. \& Thomson) Klotzsch, Abh. Konigl. Akad. Wiss. Berlin 1854: 255 (1855).

Type: Holo: K000761398, 29.viii.1849, India, Sikkim, Lachoong, 2,743-3,048 m, coll. J.D. Hooker s.n. (Image 2).

Plant dioeceous with tuberous herb, $18-35 \mathrm{~cm}$ tall. Tubercules globose, $1.5-2 \mathrm{~cm}$ diameter covered with numerous roots. Stems erect to slightly pendent, 18-35 $\mathrm{cm}$ long, glabrous, 4-5 leaves per plant. Stipules narrowly ovate to lanceolate, 5-10 x 4-7 mm, green, glabrous, apex sub-acute to obtuse, base truncate, margin entire, revolute. Leaves: petioles, 2-14 cm long, red to green, glabrous; lamina asymmetric, narrowly ovate to lanceolate, 9-17 × 6-13 cm, adaxial surface glabrous to sparsely hairs, abaxial surface glabrous, base oblique, apex acuminate, margin irregularly serrate or dentate, palmately 5-6 veined. Inflorescence terminal or axillary, dichotomously branched, $2.5-3 \mathrm{~cm}$ long; peduncles cylindrical, 4-5 mm long, glabrous, pale whitish-green, bract orbicular, 5.5-6 × 8-10 mm, connate at base, 5-6 veined. Floral bracts orbicular, 6-7 x 7-14 mm, green, glabrous, margin entire, $6-7$ veined. Pistillate flowers: pedicel 8-10 mm long, pale yellowish-green to whitish, glabrous; tepals $5-6$, unequal, white with pale yellow tinge, glabrous, margin entire; outer tepals obovate or orbicular 6-8 x 5-7 mm, apex rounded, base truncate to obtuse, 4-6 veined; inner tepals obovate to oblanceolate, $6.5-7 \times 5-6 \mathrm{~mm}$, apex slightly oblique rounded, base cuneate, 1-3 veined; styles 3, distally U-shaped and V-shaped at base, 3-3.5 mm long, fused at base, golden yellow; stigma not spiraled, papillose; ovary triangular-globose, 4-4.5 x 3-3.5 mm, glabrous, wings underdeveloped, dorsal wing minute ridge like wing and lateral wings inconspicuous, three locules, placentation xillary with 2 branches per locule; seeds oblong, $0.5 \mathrm{~mm}$ long, white.

Specimens examined: Barcode No. THIM15585, 03.viii.2019, Bhutan: Zhemgang, Malaya, $27.14549^{\circ} \mathrm{N}$, $90.86361^{\circ} \mathrm{E}, 2,628 \mathrm{~m}$, coll. S. Jamtsho, coll. No. 05.

Phenology: Flowering and fruiting from late July to September

Habitat and ecology: This species is epiphytic on Dodecadenia grandiflora in the cool broadleaved forest at 2,628 m elevation.

Distribution: India, Nepal, and new to Bhutan (Fig. 1)

Notes: Three individual plants in a single location have been observed in the field are without staminate flowers, so we couldn't examine the morphological characters of the staminate flowers at present study and will supplement in the future studies. Further study on its population trend and distribution are required to determine the conservation status of the species. No threats have been observed in the field.

\section{REFERENCES}

Camfield, R. \& M. Hughes (2018). A revision and one new species of Begonia L. (Begoniaceae, Cucurbitales) in Northeast India. European Journal of Taxonomy 396: 1-116. https://doi.org/10.5852/ ejt.2018.396

Clarke, C.B. (1879). Begoniaceae, pp. 635-656. In: Hooker J.D. (ed.) Flora of British India 2. L. Reeve, London. https://doi.org/10.5962/ bhl.title.678

Doorenbos, J., M.S.M. Sosef \& J.J.F.E. de Wilde (1998). The sections of Begonia including descriptions, keys and species lists. Studies in Begoniaceae VI. Wageningen Agricultural University Papers 98(2): 1-266.

GBIF (2020). Global Biodiversity Information Facility. Backbone Taxonomy. https://www.gbif.org/species/5284517. Accessed on 08 September 2020. https://doi.org/10.15468/39omei

Grierson, A.J.C. (1991). Begoniaceae pp. 237-246. In: Grierson A.J.C. \& D.J. Long (Eds.). Flora of Bhutan 2. Royal Botanic Garden Edinburgh, Edinburgh.

Gyeltshen, P., S. Jamtsho, S. Wangchuk \& D.B. Subba (2021). Begonia flaviflora Hara (Begoniaceae): a new record to the flora of Bhutan. Journal of Threatened Taxa 13(3): 18050-18053. https://doi. org/10.11609/jott.6709.13.3.18050-18053

Hara, H. (1971). The Flora of Eastern Himalaya. $2^{\text {nd }}$ Report: University of Tokyo Press, Tokyo pp. 83-85

Hughes, M., P.W. Moonlight, A. Jara-Muñoz, M.C. Tebbitt, H. Wilson \& M. Pullan (2015-). Begonia Resource Centre. http://padme.rbge. org.uk/begonia/. Accessed on 25 September 2020. 
Moonlight, P.W., W.H. Ardi, L.A. Padilla, K.F. Chung, D. Fuller, D. Girmansyah, R. Hollands, A. Jara-Muñoz, R. Kiew, W.C. Leong, Y. Liu, A. Mahardika, L.D.K. Marasinghe, M. O'Connor, C.I. Peng, A.J. Pérez, T. Phutthai, M. Pullan, S. Rajbhandary, C. Reynel, R.R. Rubite, J. Sang, D. Scherberich, Y.M. Shui, M.C. Tebbitt, D.C. Thomas, H.P. Wilson, N.H. Zaini \& M. Hughes (2018). Dividing and conquering the fastest-growing genus: towards a natural sectional classification of the mega-diverse genus Begonia (Begoniaceae) Taxon 67(2): 267-323. https://doi.org/10.12705/672.3

Pradhan, A., D. Rai, S.K. Barik \& A. Chettri (2019). Begonia panchtharensis (Begoniaceae), a New Record to India from Sikkim, Eastern Himalaya. The Journal of Japanese Botany 94(1): 56-57.

Rajbhandary, S., M. Hughes \& K.K. Shrestha (2010). Three new species of Begonia Sect. Platycentrum from Nepal. Gardens' Bulletin Singapore 62(1): 151-162.

Shui, Y.M., C.I. Peng \& C.Y. Wu (2002). Synopsis of the Chinese species of Begonia (Begoniaceae), with a reappraisal of sectional delimitation. Botanical Bulletin of Academia Sinica 43(4): 313-327.

Tsuechih, K., P. Ching-I \& N.J. Turland (1999). Begoniaceae. Flora Reipublicae Popularis Sinicae Beijing 52(1): 126-269. 
Dr. Albert G. Orr, Griffith University, Nathan, Australia

Dr. Sameer Padhye, Katholieke Universiteit Leuven, Belgium

Dr. Nancy van der Poorten, Toronto, Canada

Dr. Kareen Schnabel, NIWA, Wellington, New Zealand

Dr. R.M. Sharma, (Retd.) Scientist, Zoological Survey of India, Pune, India

Dr. Manju Siliwal, WILD, Coimbatore, Tamil Nadu, India

Dr. G.P. Sinha, Botanical Survey of India, Allahabad, India

Dr. K.A. Subramanian, Zoological Survey of India, New Alipore, Kolkata, India

Dr. P.M. Sureshan, Zoological Survey of India, Kozhikode, Kerala, India

Dr. R. Varatharajan, Manipur University, Imphal, Manipur, India

Dr. Eduard Vives, Museu de Ciències Naturals de Barcelona, Terrassa, Spain

Dr. James Young, Hong Kong Lepidopterists' Society, Hong Kong

Dr. R. Sundararaj, Institute of Wood Science \& Technology, Bengaluru, India

Dr. M. Nithyanandan, Environmental Department, La Ala Al Kuwait Real Estate. Co. K.S.C., Kuwait

Dr. Himender Bharti, Punjabi University, Punjab, India

Mr. Purnendu Roy, London, UK

Dr. Saito Motoki, The Butterfly Society of Japan, Tokyo, Japan

Dr. Sanjay Sondhi, TITLI TRUST, Kalpavriksh, Dehradun, India

Dr. Nguyen Thi Phuong Lien, Vietnam Academy of Science and Technology, Hanoi, Vietnam

Dr. Nitin Kulkarni, Tropical Research Institute, Jabalpur, India

Dr. Robin Wen Jiang Ngiam, National Parks Board, Singapore

Dr. Lional Monod, Natural History Museum of Geneva, Genève, Switzerland.

Dr. Asheesh Shivam, Nehru Gram Bharti University, Allahabad, India

Dr. Rosana Moreira da Rocha, Universidade Federal do Paraná, Curitiba, Brasil

Dr. Kurt R. Arnold, North Dakota State University, Saxony, Germany

Dr. James M. Carpenter, American Museum of Natural History, New York, USA

Dr. David M. Claborn, Missouri State University, Springfield, USA

Dr. Kareen Schnabel, Marine Biologist, Wellington, New Zealand

Dr. Amazonas Chagas Júnior, Universidade Federal de Mato Grosso, Cuiabá, Brasil

Mr. Monsoon Jyoti Gogoi, Assam University, Silchar, Assam, India

Dr. Heo Chong Chin, Universiti Teknologi MARA (UiTM), Selangor, Malaysia

Dr. R.J. Shiel, University of Adelaide, SA 5005, Australia

Dr. Siddharth Kulkarni, The George Washington University, Washington, USA

Dr. Priyadarsanan Dharma Rajan, ATREE, Bengaluru, India

Dr. Phil Alderslade, CSIRO Marine And Atmospheric Research, Hobart, Australia

Dr. John E.N. Veron, Coral Reef Research, Townsville, Australia

Dr. Daniel Whitmore, State Museum of Natural History Stuttgart, Rosenstein, Germany.

Dr. Yu-Feng Hsu, National Taiwan Normal University, Taipei City, Taiwan

Dr. Keith V. Wolfe, Antioch, California, USA

Dr. Siddharth Kulkarni, The Hormiga Lab, The George Washington University, Washington,

D.C., USA

Dr. Tomas Ditrich, Faculty of Education, University of South Bohemia in Ceske

Budejovice, Czech Republic

Dr. Mihaly Foldvari, Natural History Museum, University of Oslo, Norway

Dr. V.P. Uniyal, Wildlife Institute of India, Dehradun, Uttarakhand 248001, India

Dr. John T.D. Caleb, Zoological Survey of India, Kolkata, West Bengal, India

Dr. Priyadarsanan Dharma Rajan, Ashoka Trust for Research in Ecology and the Environment (ATREE), Royal Enclave, Bangalore, Karnataka, India

\section{Fishes}

Dr. Neelesh Dahanukar, IISER, Pune, Maharashtra, India

Dr. Topiltzin Contreras MacBeath, Universidad Autónoma del estado de Morelos, México

Dr. Heok Hee Ng, National University of Singapore, Science Drive, Singapore

Dr. Rajeev Raghavan, St. Albert's College, Kochi, Kerala, India

Dr. Robert D. Sluka, Chiltern Gateway Project, A Rocha UK, Southall, Middlesex, UK

Dr. E. Vivekanandan, Central Marine Fisheries Research Institute, Chennai, India

Dr. Davor Zanella, University of Zagreb, Zagreb, Croatia

Dr. A. Biju Kumar, University of Kerala, Thiruvananthapuram, Kerala, India

Dr. Akhilesh K.V., ICAR-Central Marine Fisheries Research Institute, Mumbai Research

Centre, Mumbai, Maharashtra, India

Dr. J.A. Johnson, Wildlife Institute of India, Dehradun, Uttarakhand, India

\section{Amphibians}

Dr. Sushil K. Dutta, Indian Institute of Science, Bengaluru, Karnataka, India

Dr. Annemarie Ohler, Muséum national d'Histoire naturelle, Paris, France

\section{Reptiles}

Dr. Gernot Vogel, Heidelberg, Germany

Dr. Raju Vyas, Vadodara, Gujarat, India

Dr. Pritpal S. Soorae, Environment Agency, Abu Dubai, UAE.

Prof. Dr. Wayne J. Fuller, Near East University, Mersin, Turkey

Prof. Chandrashekher U. Rivonker, Goa University, Taleigao Plateau, Goa. India

Dr. S.R. Ganesh, Chennai Snake Park, Chennai, Tamil Nadu, India

Dr. Himansu Sekhar Das, Terrestrial \& Marine Biodiversity, Abu Dhabi, UAE
Birds

Dr. Hem Sagar Baral, Charles Sturt University, NSW Australia

Dr. Chris Bowden, Royal Society for the Protection of Birds, Sandy, UK

Dr. Priya Davidar, Pondicherry University, Kalapet, Puducherry, India

Dr. J.W. Duckworth, IUCN SSC, Bath, UK

Dr. Rajah Jayapal, SACON, Coimbatore, Tamil Nadu, India

Dr. Rajiv S. Kalsi, M.L.N. College, Yamuna Nagar, Haryana, India

Dr. V. Santharam, Rishi Valley Education Centre, Chittoor Dt., Andhra Pradesh, India

Dr. S. Balachandran, Bombay Natural History Society, Mumbai, India

Mr. J. Praveen, Bengaluru, India

Dr. C. Srinivasulu, Osmania University, Hyderabad, India

Dr. K.S. Gopi Sundar, International Crane Foundation, Baraboo, USA

Dr. Gombobaatar Sundev, Professor of Ornithology, Ulaanbaatar, Mongolia

Prof. Reuven Yosef, International Birding \& Research Centre, Eilat, Israel

Dr. Taej Mundkur, Wetlands International, Wageningen, The Netherlands

Dr. Carol Inskipp, Bishop Auckland Co., Durham, UK

Dr. Tim Inskipp, Bishop Auckland Co, Durham, UK

Dr. V. Gokula, National College, Tiruchirappalli, Tamil Nadu, India

Dr. Arkady Lelej, Russian Academy of Sciences, Vladivostok, Russia

Dr. Simon Dowell, Science Director, Chester Zoo, UK

Dr. Mário Gabriel Santiago dos Santos, Universidade de Trás-os-Montes e Alto Douro,

Quinta de Prados, Vila Real, Portugal

Dr. Grant Connette, Smithsonian Institution, Royal, VA, USA

Dr. M. Zafar-ul Islam, Prince Saud Al Faisal Wildlife Research Center, Taif, Saudi Arabia

Mammals

Dr. Giovanni Amori, CNR - Institute of Ecosystem Studies, Rome, Italy

Dr. Anwaruddin Chowdhury, Guwahati, India

Dr. David Mallon, Zoological Society of London, UK

Dr. Shomita Mukherjee, SACON, Coimbatore, Tamil Nadu, India

Dr. Angie Appel, Wild Cat Network, Germany

Dr. P.O. Nameer, Kerala Agricultural University, Thrissur, Kerala, India

Dr. Ian Redmond, UNEP Convention on Migratory Species, Lansdown, UK

Dr. Heidi S. Riddle, Riddle's Elephant and Wildlife Sanctuary, Arkansas, USA

Dr. Karin Schwartz, George Mason University, Fairfax, Virginia.

Dr. Lala A.K. Singh, Bhubaneswar, Orissa, India

Dr. Mewa Singh, Mysore University, Mysore, India

Dr. Paul Racey, University of Exeter, Devon, UK

Dr. Honnavalli N. Kumara, SACON, Anaikatty P.O., Coimbatore, Tamil Nadu, India

Dr. Nishith Dharaiya, HNG University, Patan, Gujarat, India

Dr. Spartaco Gippoliti, Socio Onorario Società Italiana per la Storia della Fauna "Giuseppe

Altobello", Rome, Italy

Dr. Justus Joshua, Green Future Foundation, Tiruchirapalli, Tamil Nadu, India

Dr. H. Raghuram, The American College, Madurai, Tamil Nadu, India

Dr. Paul Bates, Harison Institute, Kent, UK

Dr. Jim Sanderson, Small Wild Cat Conservation Foundation, Hartford, USA

Dr. Dan Challender, University of Kent, Canterbury, UK

Dr. David Mallon, Manchester Metropolitan University, Derbyshire, UK

Dr. Brian L. Cypher, California State University-Stanislaus, Bakersfield, CA

Dr. S.S. Talmale, Zoological Survey of India, Pune, Maharashtra, India

Prof. Karan Bahadur Shah, Budhanilakantha Municipality, Kathmandu, Nepal

Dr. Susan Cheyne, Borneo Nature Foundation International, Palangkaraja, Indonesia

Dr. Hemanta Kafley, Wildlife Sciences, Tarleton State University, Texas, USA

\section{Other Disciplines}

Dr. Aniruddha Belsare, Columbia MO 65203, USA (Veterinary)

Dr. Mandar S. Paingankar, University of Pune, Pune, Maharashtra, India (Molecular)

Dr. Jack Tordoff, Critical Ecosystem Partnership Fund, Arlington, USA (Communities)

Dr. Ulrike Streicher, University of Oregon, Eugene, USA (Veterinary)

Dr. Hari Balasubramanian, EcoAdvisors, Nova Scotia, Canada (Communities)

Dr. Rayanna Hellem Santos Bezerra, Universidade Federal de Sergipe, São Cristóvão, Brazil

Dr. Jamie R. Wood, Landcare Research, Canterbury, New Zealand

Dr. Wendy Collinson-Jonker, Endangered Wildlife Trust, Gauteng, South Africa

Dr. Rajeshkumar G. Jani, Anand Agricultural University, Anand, Gujarat, India

Dr. O.N. Tiwari, Senior Scientist, ICAR-Indian Agricultural Research Institute (IARI), New

Delhi, India

Dr. L.D. Singla, Guru Angad Dev Veterinary and Animal Sciences University, Ludhiana, India

Dr. Rupika S. Rajakaruna, University of Peradeniya, Peradeniya, Sri Lanka

Dr. Bahar Baviskar, Wild-CER, Nagpur, Maharashtra 440013, India

Reviewers 2018-2020

Due to pausity of space, the list of reviewers for 2018-2020 is available online.
The opinions expressed by the authors do not reflect the views of the Journal of Threatened Taxa, Wildlife Information Liaison Development Society, Zoo Outreach Organization, or any of the partners. The journal, the publisher, the host, and the partners are not responsible for the accuracy of the political boundaries shown in the maps by the authors.

\footnotetext{
Print copies of the Journal are available at cost. Write to:

The Managing Editor, JoTT,

c/o Wildlife Information Liaison Development Society,

No. 12, Thiruvannamalai Nagar, Saravanampatti - Kalapatti Road,

Saravanampatti, Coimbatore, Tamil Nadu 641035, India

ravi@threatenedtaxa.org
} 


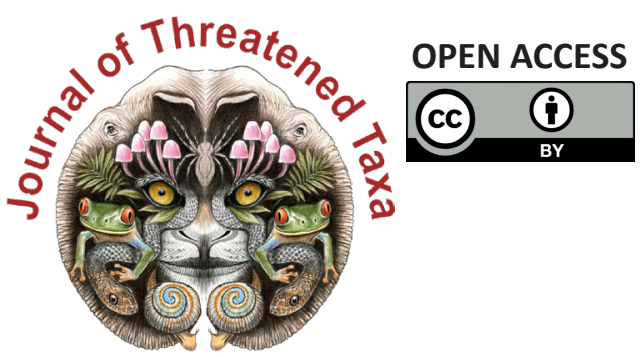

www.threatenedtaxa.org

The Journal of Threatened Taxa (JoTT) is dedicated to building evidence for conservation globally by publishing peer-reviewed articles online every month at a reasonably rapid rate at www.threatenedtaxa.org. All articles published in JoTT are registered under Creative Commons Attribution 4.0 International License unless otherwise mentioned. JoTT allows allows unrestricted use, reproduction, and distribution of articles in any medium by providing adequate credit to the author(s) and the source of publication.

\section{ISSN $0974-7907$ (Online) | ISSN $0974-7893$ (Print)}

\section{September 2021 | Vol. 13 | No. 11 | Pages: 19431-19674 Date of Publication: 26 September 2021 (Online \& Print) DOI: 10.11609/jott.2021.13.11.19431-19674}

Articles

Understanding human-flying fox interactions in the Agusan Marsh Wildlife Sanctuary as basis for conservation policy interventions

- Sherryl L. Paz \& Juan Carlos T. Gonzalez, Pp. 19431-19447

Argentinian odonates (dragonflies and damselflies): current and future distribution and discussion of their conservation

- A. Nava-Bolaños, D.E. Vrech, A.V. Peretti \& A. Córdoba-Aguilar, Pp. 19448-19465

\section{Communications}

The diel activity pattern of small carnivores of Western Ghats, India: a case study at Nelliampathies in Kerala, India

- Devika Sanghamithra \& P.O. Nameer, Pp. 19466-19474

Distribution and threats to Smooth-Coated Otters Lutrogale perspicillata (Mammalia: Carnivora: Mustelidae) in Shuklaphanta National Park, Nepal

- Gopi Krishna Joshi, Rajeev Joshi \& Bishow Poudel, Pp. 19475-19483

Wildlife hunting practices of the Santal and Oraon communities in Rajshahi, Bangladesh - Azizul Islam Barkat, Fahmida Tasnim Liza, Sumaiya Akter, Ashikur Rahman Shome \& M. Fazle Rabbe, Pp. 19484-19491

Ethnozoological use of primates in northeastern India

- Deborah Daolagupu, Nazimur Rahman Talukdar \& Parthankar Choudhury, Pp. 19492-19499

Factors influencing the flush response and flight initiation distance of three owl species in the Andaman Islands

- Shanmugavel Sureshmarimuthu, Santhanakrishnan Babu, Honnavalli Nagaraj Kumara \& Nagaraj Rajeshkumar, Pp. 19500-19508

Birds of Barandabhar Corridor Forest, Chitwan, Nepal

- Saneer Lamichhane, Babu Ram Lamichhane, Kapil Pokharel, Pramod Raj Regmi, Tulasi Prasad Dahal, Santosh Bhattarai, Chiranjibi Prasad Pokheral, Pabitra Gotame,

Trishna Rayamajhi, Ram Chandra Kandel \& Aashish Gurung, Pp. 19509-19526

On some additions to the amphibians of Gunung Inas Forest Reserve, Kedah,

Peninsular Malaysia

- Shahriza Shahrudin, Pp. 19527-19539

Reviews

A review of research on the distribution, ecology, behaviour, and conservation of the Slender Loris Loris lydekkerianus (Mammalia: Primates: Lorisidae) in India

- Mewa Singh, Mridula Singh, Honnavalli N. Kumara, Shanthala Kumar, Smitha D. Gnanaolivu \& Ramamoorthy Sasi, Pp. 19540-19552

Bivalves (Mollusca: Bivalvia) in Malaysian Borneo: status and threats

- Abdulla-Al-Asif, Hadi Hamli, Abu Hena Mustafa Kamal, Mohd Hanafi Idris, Geoffery James Gerusu, Johan Ismail \& Muyassar H. Abualreesh, Pp. 19553-19565

Disentangling earthworm taxonomic stumbling blocks using molecular markers

- Azhar Rashid Lone, Samrendra Singh Thakur, Nalini Tiwari, Olusola B. Sokefun \&

Shweta Yadav, Pp. 19566-19579

A reference of identification keys to plant-parasitic nematodes (Nematoda: Tylenchida) Tylenchomorpha)

- Reza Ghaderi, Manouchehr Hosseinvand \& Ali Eskandari, Pp. 19580-19602

Short Communications

Catalogue of herpetological specimens from Meghalaya, India at the Salim Ali Centre for Ornithology and Natural History

-S.R. Chandramouli, R.S. Naveen, S. Sureshmarimuthu, S. Babu, P.V. Karunakaran \&

Honnavalli N. Kumara, Pp. 19603-19610
A preliminary assessment of odonate diversity along the river Tirthan, Great Himalayan National Park Conservation Area, India with reference to the impact of climate change - Amar Paul Singh, Kritish De, Virendra Prasad Uniyal \& Sambandam Sathyakumar, Pp. 19611-19615

A checklist of orthopteran fauna (Insecta: Orthoptera) with some new records in the cold arid region of Ladakh, India

- M. Ali, M. Kamil Usmani, Hira Naz, Tajamul Hassan Baba \& Mohsin Ali, Pp. 19616-19625

New distribution records of two Begonias to the flora of Bhutan

- Phub Gyeltshen \& Sherab Jamtsho, Pp. 19626-19631

Rediscovery of Aponogeton lakhonensis A. Camus (Aponogetonaceae): a long-lost aquatic plant of India

- Debolina Dey, Shrirang Ramchandra Yadav \& Nilakshee Devi, Pp. 19632-19635

Glyphochloa acuminata (Hack.) Clayton var. laevis (Poaceae): a new variety from central Western Ghats of Karnataka, India

- H.U. Abhijit \& Y.L. Krishnamurthy, Pp. 19636-19639

A cytomorphological investigation of three species of the genus Sonchus L. (Asterales: Asteraceae) from Punjab, India

- M.C. Sidhu \& Rai Singh, Pp. 19640-19644

Dryopteris lunanensis (Dryopteridaceae) - an addition to the pteridophytic diversity of India

- Chhandam Chanda, Christopher Roy Fraser-Jenkins \& Vineet Kumar Rawat, Pp. 1964519648

Notes

First record of Spotted Linsang Prionodon pardicolor (Mammalia: Carnivora:

Prionodontidae) with photographic evidence in Meghalaya, India

- Papori Khatonier \& Adrian Wansaindor Lyngdoh, Pp. 19649-19651

First record of the Eastern Cat Snake Boiga gocool (Gray, 1835) (Squamata: Colubridae) from Tripura, India

- Sumit Nath, Biswajit Singh, Chiranjib Debnath \& Joydeb Majumder, Pp. 19652-19656

First record of the genus Tibetanja (Lepidoptera: Eupterotidae: Janinae) from India - Alka Vaidya \& H. Sankararaman, Pp. 19657-19659

Austroborus cordillerae (Mollusca: Gastropoda) from central Argentina: a rare, little-known land snail

- Sandra Gordillo, Pp. 19660-19662

Intestinal coccidiosis (Apicomplexa: Eimeriidae) in a Himalayan Griffon Vulture Gyps himalayensis

- Vimalraj Padayatchiar Govindan, Parag Madhukar Dhakate \& Ayush Uniyal, Pp. 1966319664

Two new additions to the orchid flora of Assam, India

- Sanswrang Basumatary, Sanjib Baruah \& Lal Ji Singh, Pp. 19665-19670

Wildlife art and illustration - combining black and white ink drawings with colour: some experiments in Auroville, India

- M. Eric Ramanujam \& Joss Brooks, Pp. 19671-19674
Publisher \& Host

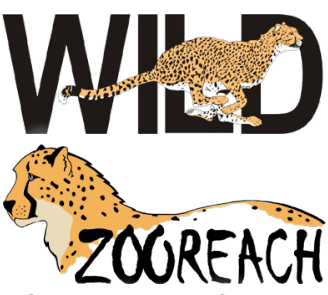

